\title{
Analisis Antropometri Mahasiswa Untuk Desain Mebel pada Program Studi Desain Interior Universitas ' $X$ ' di Surabaya
}

\author{
Carolina $^{1^{*}}$, Mariana Wibowo ${ }^{2}$, dan Muhamad Taufan Rizqi ${ }^{3}$ \\ ${ }^{1,2,3)}$ Program Studi Desain Interior, Universitas Kristen Petra, Surabaya \\ $\left.{ }^{*}\right)$ e-mail korespondensi: olincarolinago@gmail.com \\ doi: https://doi.org/10.24843/JEI.2020.v06.i02.p07
}

Article Received: 10 July 2020; Accepted: 16 December 2020 Published: 31 December 2020

\begin{abstract}
Abstrak
Kegiatan belajar mengajar bagi mahasiswa desain interior Universitas ' $\mathrm{X}$ ', dari semester awal hingga semester akhir memiliki aktivitas yang cukup berbeda. Kebutuhan mebel pengisi ruang interior pun tentu berbeda, sehingga dibutuhkannya mebel yang dapat sesuai dan nyaman bagi pengguna untuk menunjang aktivitas tersebut. Faktor utama yang dapat mendukung kesesuaian dan kenyamanan aktivitas terhadap mebel yang digunakan adalah pentingnya data ukuran tubuh mahasiswa, agar data tersebut dapat menjadi pedoman perancangan desain. Penelitian ini bertujuan untuk mendapatkan data antropometri mahasiswa program studi desain interior yang lebih akurat dan sesuai, sehingga penelitian dapat menjadi acuan untuk perancangan mebel pendukung aktivitas di kelas kuliah dan studio desain interior. Metode penelitian yang digunakan adalah campuran metode kualitatif (studi lapangan dan observasi) dan kuantitatif (survei dalam bentuk kuisioner) untuk dapat menampilkan fakta data antopometri serta pendapat pengguna terhadap kenyamanan dan kepuasan penggunaan mebel. Hasil dari penelitian ini adalah ukuran antropometri mahasiswa desain interior untuk dapat menjadi acuan perancangan mebel penunjang aktivitas program studi desain interior Universitas ' $\mathrm{X}$ ' dan data dimensi ukuran mebel yang sesuai dengan data antropometri mahasiswa.
\end{abstract}

Kata kunci: antropometri, desain interior, mahasiswa

\section{Student Anthropomethry Analysis for Furniture Design in Interior Design Study Program 'X'University in Surabaya}

\begin{abstract}
Teaching and learning activities for interior design students of ' $X$ ' University, from the begining of semester to the end of semesterhave quite different activities. The need for interior space fill furniture is certainly different, so the need for furniture that could be suitable and comfortable for users to support these activities. The main factor that can support the suitability and conveniece of activities for the furniture used is the importance of student body size data, so that the data can be used as design guidelines. This study aims to obtain anthropometric data for interior design students that are more accurate and appropriate, so that research could be a reference for designing furniture supporting activities in lecture classes and interior design studios. The research method used is a mixture of qualitative methods (field studies and observations) and quantitative (surveys in the form of questionnaires) to be able to display the facts of antopometric data and user opinions on the convenience and satisfaction of using furniture. The results of this study are the anthropometry measurements of interior design students to become a reference for the design of furniture supporting the activities of the ' $X$ ' University interior design study program and the dimensions of furniture size data in accordance with student anthropometric data.
\end{abstract}

Keyword: anthropometry, interior design, student 


\section{PENDAHULUAN}

Antropometri adalah suatu bidang ilmu yang bertujuan khusus untuk mempelajari ukuran tubuh manusia, ukuran tubuh manusia dapat berbeda-beda disebabkan oleh berbagai faktor. Tujuan dari pengukuran perbedaan tubuh adalah agar dapat mengetahui acuan rata-rata ukuran tubuh, sehingga tidak terlalu menyimpang jauh dari yang sebenarnya dan dapat mengurangi tingkat kecelakaan kerja (Iridiastadi \& Yassierli, 2015). Kesesuaian ukuran tubuh dengan ukuran mebel untuk menunjang kegiatan/aktivitas bertujuan agar aktivitas pengguna efektif, efisien, dan juga dapat meningkatkan produktivitas kerja (Iridiastadi \& Yassierli, 2015).

Menurut pengamatan lapangan, kuisioner, dan wawancara terhadap mahasiswa Program Studi Desain Interior Universitas X, terbukti bahwa mebel yang digunakan sebagai sarana pembelajaran di Universitas X masih belum sesuai dengan kebutuhan dari pengguna. Hal ini disebabkan karena ukuran mebel yang digunakan masih belum berpedoman pada ukuran tubuh pengguna. Mahasiswa Program Studi Desain Interior Universitas X, memiliki jumlah perempuan (354) lebih banyak dibanding laki-laki (112), dari data Tabel 1 terlihat bahwa ukuran tubuh mahasiswa laki-laki dan perempuan sangat berbeda. Begitu pula dengan penelitian dari Ismaila (2013) terhadap mahasiswa Nigeria dan penelitian dari Octivjani (2011), yang menjelaskan bahwa ukuran tubuh mahasiswa laki-laki lebih besar dari perempuan, dari penelitian tersebut juga didapatkan bahwa ukuran tubuh antara mahasiswa Nigeria dengan mahasiswa Indonesia memiliki ukuran yang berbeda. Perbedaan ukuran tubuh tersebutlah yang dapat mempengaruhi ukuran untuk perancangan mebel agar ukuran mebel dapat disesuaikan dengan kebutuhan dan ukuran tubuh penggunanya.

Perbedaan dari antropometri tersebut merupakan salah satu alasan pentingnya melakukan penelitian ini agar dapat menentukan ukuran mebel yang sesuai dengan pengguna. Penelitian tentang antropometri terhadap mahasiswa Program Studi Desain Interior ini bertujuan untuk menghasilkan antropometri mahasiswa perempuan dan laki-laki di Universitas X. Adapun data antropometri yang didapatkan juga dapat menjadi bahan pertimbangan acuan ukuran mebel penunjang aktivitas di kampus yang sesuai dengan ukuran penggunanya. Sehingga untuk merancang mebel kedepannya dapat disesuaikan dengan ukuran dari data antropometri dipenelitian ini, dan pertimbangan aktivitas pengguna yang berbeda dari penelitian ini.

\section{METODE}

Penelitian ini dilakukan dengan pengamatan terhadap pengguna mebel (aktivitas dan tingkah laku), pengukuran antropometri dengan metode statis. Subjek pada penelitian ini adalah mahasiswa Program Studi Desain Interior angkatan 2016-2019, di Universitas ' $X$ Surabaya. Pengambilan sampel secara acak menggunakan rumus slovin dengan margin of error sebesar 5\%, total sampel 215 data mahasiswa (70 laki-laki dan 145 perempuan) dari populasi 466 mahasiswa aktif, pengamatan dan pengukuran dilakukan dari bulan Januari hingga Maret 2020. Penelitian ini juga disertai dengan pembagian kuisioner dengan pertanyaan seputar kesesuaian ukuran dan kebutuhan mebel bagi pengguna. Hasil dari penelitian ini adalah ukuran mebel yang sesuai dengan kebutuhan dan ukuran tubuh mahasiswa, dengan pertimbangan dari pengamatan lapangan dan perhitungan berdasarkan sumber literatur. Penelitian ini dilakukan secara terstruktur berdasarkan diagram alur penelitian yang telah dilakukan, seperti pada Gambar 1. 


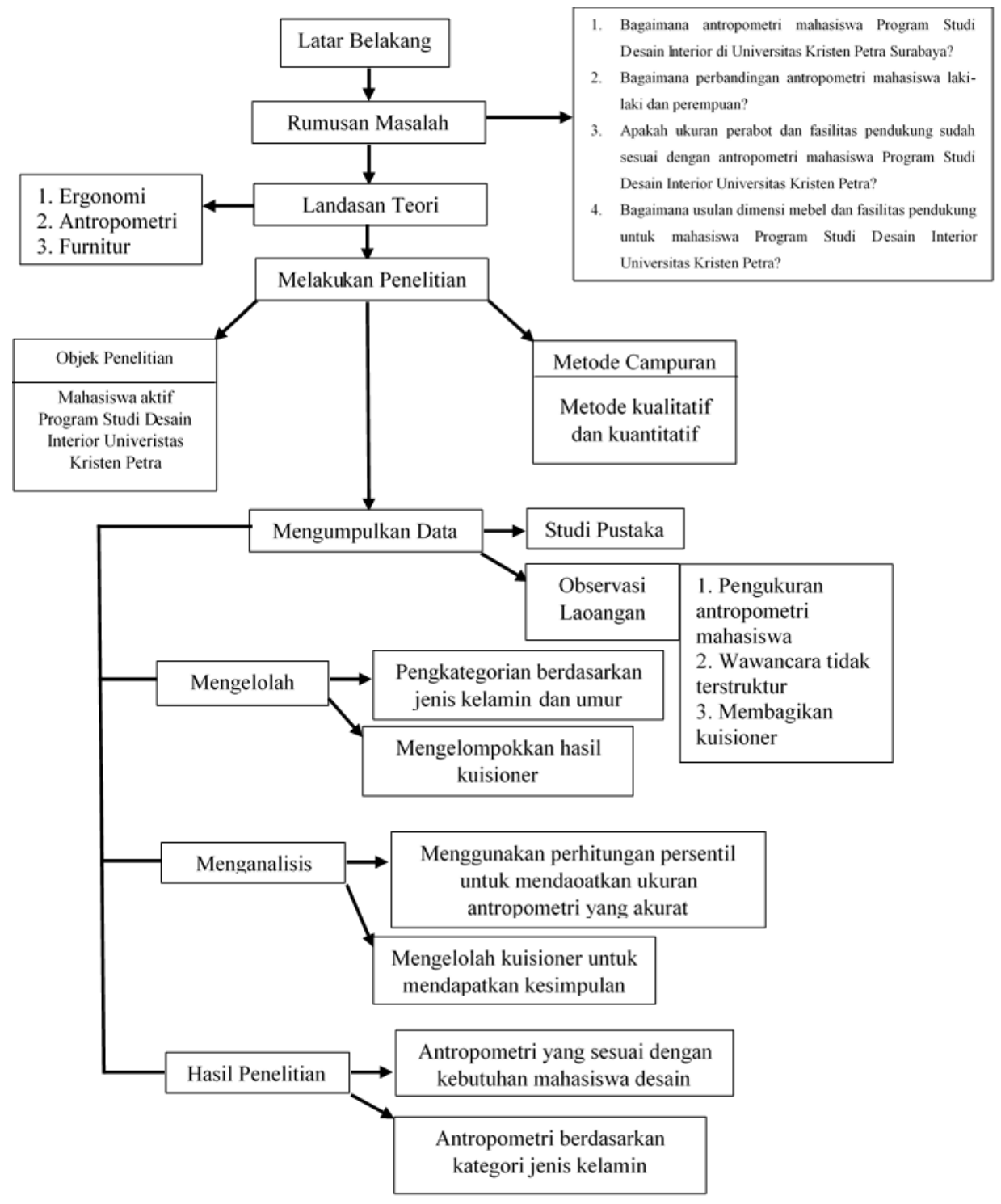

Gambar 1. Diagram Alur Penelitian

\section{HASIL DAN PEMBAHASAN}

Penelitian ini dilakukan di Universitas ' $\mathrm{X}$ ' khususnya untuk mebel penunjang aktivitas di ruangan yang digunakan mahasiswa Program Studi Desain Interior, seperti: Material Library, Laboratorium Komputer, Laboratorium Bahan, Laboratorium Kayu, Laboratorium Tekstil, Ruang Kelas, dan Studio Interior. Berikut ini merupakan antropometri mahasiswa yang telah dikelola:

Tabel 1

Antropometri mahasiswa program studi desain interior tahun 2020

\begin{tabular}{ccccc}
\hline \multirow{2}{*}{ No } & \multirow{2}{*}{ Dimensi tubuh } & \multicolumn{3}{c}{ Statistik deskriptif $(\mathrm{cm})$} \\
& & Persentil & Pria & Wanita \\
\hline \multirow{2}{*}{ Tinggi tubuh pada posisi berdiri tegak } & Rerata & 171 & 158 \\
& & Sd & 7 & 5 \\
& & P5 & 160 & 150 \\
& & P95 & 182 & 166
\end{tabular}


2 Tinggi mata

Rerata

159

147

$\mathrm{Sd}$

P5

6

5

P95

148

139

$3 \quad$ Tinggi bahu

Rerata

169

155

$\mathrm{Sd}$

P5

P95

140

130

6

5

130

121

$4 \quad$ Tinggi siku

Rerata

150

138

$\mathrm{Sd}$

109

99

11

6

$\begin{array}{lll}\text { P5 } & 90 & 89\end{array}$

$\begin{array}{lll}\text { P95 } & 128 & 109\end{array}$

$5 \quad$ Cengkraman tangan pada posisi rileks

Rerata

74

69 ke bawah

Sd

4

P5

P95

67

4

Rerata

81

63

6 Tinggi badan posisi duduk

$$
\mathrm{Sd}
$$

P5

P95

7 Tinggi mata posisi duduk

Rerata

$\mathrm{Sd}$

P5

P95

8 Tinggi bahu posisi duduk

Rerata

89

5

81

97

77

4

$\begin{array}{lll}\mathrm{Sd} & 4 & 48\end{array}$

$\begin{array}{lll}\text { P5 } & 51 & 48\end{array}$

P95

64

9 Tinggi siku posisi duduk

Rerata

$23 \quad 25$

$\begin{array}{lll}\mathrm{Sd} & 4 & 3\end{array}$

$\begin{array}{lll}\text { P5 } & 17 & 20\end{array}$

10 Tebal paha

P95

Rerata

$\mathrm{Sd}$

P5

P95

30

30

Rerata

$\mathrm{Sd}$

P5

P95

12 Jarak dari lipat lutut ke pantat

Rerata

$\mathrm{Sd}$

P5

P95

Rerata

$\mathrm{Sd}$

P5

P95

Rerata

$\mathrm{Sd}$

P1

P5

55

$62 \quad 59$

$46 \quad 47$

$3 \quad 3$

$47 \quad 45$

$57 \quad 53$

14 Tinggi lipat lutut

43

32

$\begin{array}{lc}3 & 2 \\ 36 & 36\end{array}$

P95

38

36 


\begin{tabular}{|c|c|c|c|c|}
\hline \multirow[t]{4}{*}{15} & \multirow[t]{3}{*}{ Lebar bahu } & Rerata & 46 & 45 \\
\hline & & $\mathrm{Sd}$ & 4 & 3 \\
\hline & & P5 & 40 & 39 \\
\hline & & P95 & 53 & 50 \\
\hline \multirow[t]{4}{*}{16} & \multirow[t]{4}{*}{ Lebar panggul } & Rerata & 20 & 23 \\
\hline & & $\mathrm{Sd}$ & 5 & 6 \\
\hline & & P5 & 12 & 12 \\
\hline & & P95 & 47 & 45 \\
\hline \multirow[t]{4}{*}{17} & \multirow[t]{4}{*}{ Tebal dada } & Rerata & 20 & 23 \\
\hline & & $\mathrm{Sd}$ & 5 & 6 \\
\hline & & P5 & 12 & 12 \\
\hline & & P95 & 28 & 33 \\
\hline \multirow[t]{4}{*}{18} & \multirow[t]{4}{*}{ Tebal perut } & Rerata & 20 & 19 \\
\hline & & $\mathrm{Sd}$ & 6 & 4 \\
\hline & & P5 & 10 & 13 \\
\hline & & P95 & 31 & 25 \\
\hline \multirow[t]{4}{*}{19} & \multirow[t]{4}{*}{ Jarak dari siku ke ujung jari } & Rerata & 47 & 44 \\
\hline & & $\mathrm{Sd}$ & 3 & 2 \\
\hline & & P5 & 41 & 40 \\
\hline & & P95 & 53 & 48 \\
\hline \multirow[t]{4}{*}{20} & \multirow[t]{4}{*}{ Lebar kepala } & Rerata & 18 & 19 \\
\hline & & $\mathrm{Sd}$ & 2 & 2 \\
\hline & & P5 & 15 & 16 \\
\hline & & P95 & 21 & 22 \\
\hline \multirow[t]{4}{*}{21} & \multirow[t]{4}{*}{ Panjang tangan } & Rerata & 19 & 18 \\
\hline & & $\mathrm{Sd}$ & 1 & 1 \\
\hline & & P5 & 17 & 16 \\
\hline & & P95 & 20 & 20 \\
\hline \multirow[t]{4}{*}{22} & \multirow[t]{4}{*}{ Lebar tangan } & Rerata & 11 & 11 \\
\hline & & $\mathrm{Sd}$ & 1 & 1 \\
\hline & & P5 & 9 & 9 \\
\hline & & P95 & 12 & 12 \\
\hline \multirow[t]{4}{*}{23} & \multirow[t]{4}{*}{ Jarak bentang dari ujung jari } & Rerata & 172 & 163 \\
\hline & & $\mathrm{Sd}$ & 9 & 7 \\
\hline & & P5 & 158 & 152 \\
\hline & & P95 & 187 & 174 \\
\hline \multirow[t]{4}{*}{24} & \multirow{4}{*}{$\begin{array}{l}\text { Tinggi pegangan tangan pada posisi } \\
\text { tangan vertikal ke atas dan berdiri tegak }\end{array}$} & Rerata & 207 & 197 \\
\hline & & $\mathrm{Sd}$ & 14 & 8 \\
\hline & & P5 & 184 & 184 \\
\hline & & P95 & 230 & 210 \\
\hline \multirow[t]{4}{*}{25} & \multirow{4}{*}{$\begin{array}{l}\text { Tinggi pegangan tangan pada posisi } \\
\text { tangan vertikal ke atas dan duduk }\end{array}$} & Rerata & 141 & 123 \\
\hline & & $\mathrm{Sd}$ & 21 & 20 \\
\hline & & P5 & 106 & 90 \\
\hline & & P95 & 175 & 156 \\
\hline \multirow[t]{4}{*}{26} & Jarak genggaman tangan ke punggung & Rerata & 72 & 66 \\
\hline & & $\mathrm{Sd}$ & 6 & 5 \\
\hline & & P5 & 62 & 58 \\
\hline & & P95 & 82 & 74 \\
\hline
\end{tabular}

Mebel penunjang aktivitas untuk mahasiswa Program Studi Desain Interior adalah meja kerja laboratorium, meja komputer, meja studio, meja dan kursi kelas, kursi studio, kursi 
laboratorium, loker, dan display. Berikut ini adalah hasil analisis dan usulan ukuran mebel yang disesuaikan dengan antropometri dan kebutuhan mahasiswa. Untuk perhitungan ukuran meja sesuai antropometeri diperoleh hasil seperti Tabel 2.

Tabel 2

Analisis Perhitungan Usulan Ukuran Meja

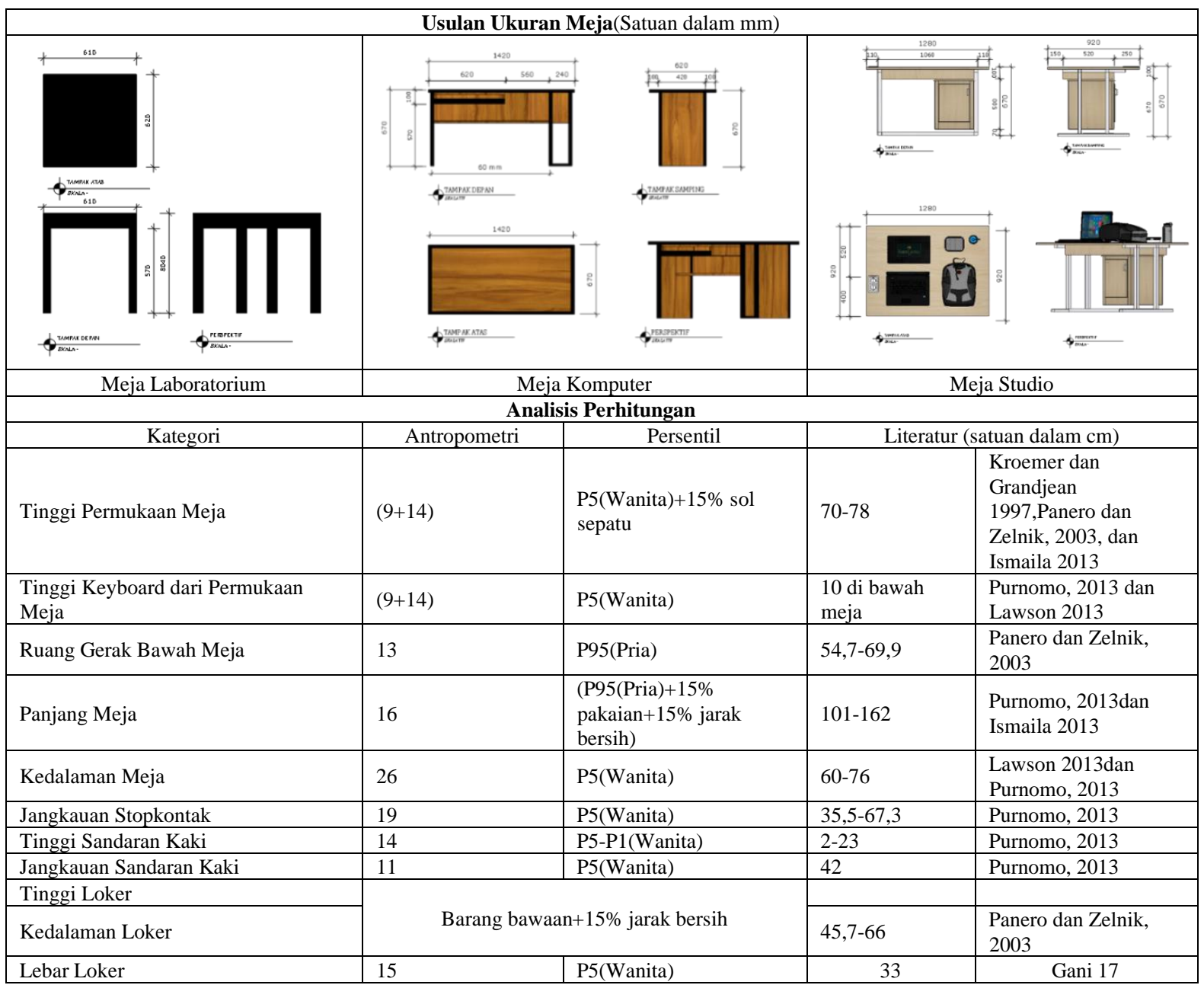

Menurut Kroemer dan Grandjean (1997), ketinggian permukaan meja harus berada di bawah siku (tinggi siku posisi duduk dan tinggi lipat lutut) agar pengguna tidak perlu memaksakan bahunya untuk naik mengimbangi aktivitasnya. Perhitungan menggunakan persentil kecil agar pengguna bertubuh kecil dapat menggunakan dengan nyaman dan tidak memaksakan diri. Menurut Ismaila (2013), perhitungan tinggi permukaan meja harus ditambahkan $15 \%$ untuk perkiraan menggunakan sol sepatu.

Menurut Purnomo (2013), perhitungan untuk tinggi peletakkan keyboard menggunakan tinggi siku duduk ditambah dengan tinggi lipat lutut oleh persentil kecil. Agar siku pengguna berukuran tubuh lebih kecil sejajar dengan tinggi keyboard. Menurut Panero dan Zelnik (2003), untuk menghitung ruang gerak di bawah meja harus menggunakan ukuran tinggi lutut dengan mempertimbangkan persentil besar agar meja tidak terbentur lutut dari pengguna bertubuh besar.

Menurut Ismaila (2013), panjang meja yang dibutuhkan untuk 1 orang menggunakan perhitungan dari lebar panggul persentil 95 ditambahkan 15\% untuk pakaian dan $15 \%$ untuk jarak bersih. Sedangkan perhitungan untuk lebar meja untuk jarak ideal sebaiknya menggunakan jangkauan tangan horizontal ke depan oleh persentil kecil, agar pengguna 
berukuran tubuh kecil tidak memaksa dalam menjangkau area terjauh meja (Purnomo, 2013). Khusus untuk panjang meja komputer di atasdigunakan untuk 2 orang, sehingga panjang meja awal dikali 2 orang $(122 \mathrm{~cm})$ dan ditambahkan kebutuhan lain untuk menempatkan CPU dengan ukuran maksimal $20 \mathrm{~cm}$, jadi panjang meja yang dibutuhkan untuk 2 orang adalah 142 $\mathrm{cm}$.Panjang dan lebar untuk meja studio dihitung dengan mempertimbangkan barang yang akan diletakkan oleh mahasiswa menurut kuisioner (Laptop 44x25 cm, sketchbook A3 42x30 $\mathrm{cm}$, dan tas laptop 15 in)

Menurut Purnomo (2013), jangkauan normal di meja kerja saat duduk sebaiknya mempetimbangkan ukuran dari jarak siku ke ujung jari P5, hal ini agar pengguna tidak perlu berdiri atau menggapai terlalu jauh saat menjangkaunya. Perhitungan untuk ketinggian sandaran kaki dapat dihitung dengan mengurangi P5-P1 dari tinggi lipat lutut (Purnomo, 2013). Menghitung jangkauan sandaran kaki dengan memperkirakan letak kaki pengguna saat menggunakan meja, pengguna akan cenderung mendaratkan kaki di area bawah meja saat duduk, sehingga dapat menghitung dengan jarak dari pantat ke lutut P5 agar pengguna berukuran tubuh kecil dapat menjangkau sandaran kaki (Purnomo, 2013).

Selanjutnya untuk analisis perhitungan ukuran kursi sesuai dengan anthropomteri, disajikan seperti pada Tabel 3.

Tabel 3

Analisis Perhitungan Usulan Ukuran Kursi

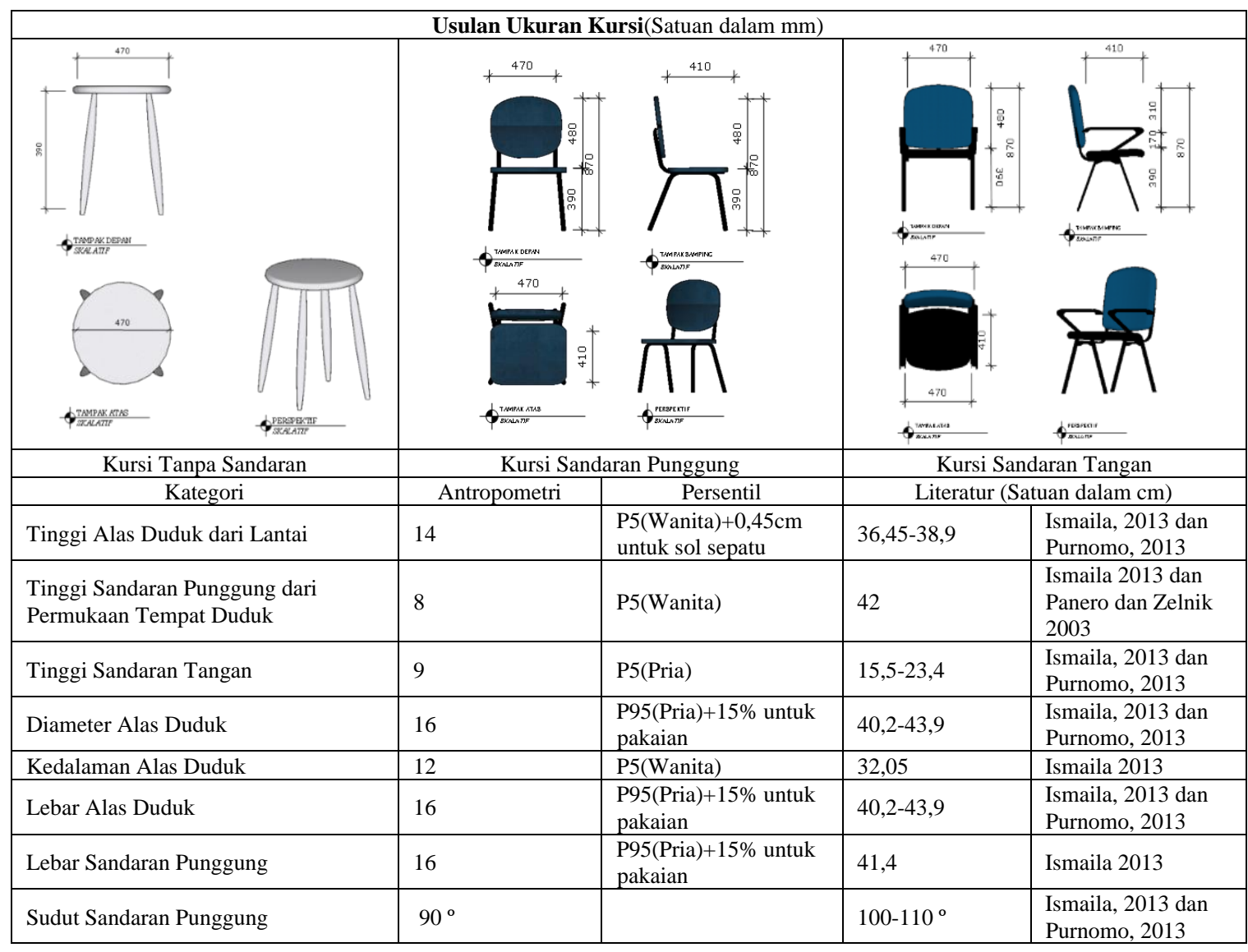

Menurut Purnomo (2013), pengguna (terutama persentil kecil) harus menapakkan kakinya ke lantai saat menggunakan kursi, idealnya ketinggian alas duduk harus sama dengan tinggi lipat lutut agar lutut pengguna dapat membentuk siku $90^{\circ}$. Perhitungan tinggi alas duduk juga perlu ditambahkan 0,45 $\mathrm{cm}$ untuk memperhitungkan ketinggian dari sol sepatu pengguna (Ismaila, 2013). Menurut Panero dan Zelnik, standar untuk ketinggian punggung harus dapat mengakomodasi seluruh punggung pengguna, namun dalam penggunaanya pengguna tetap 
dapat bebas bergerak. Menurut Ismaila (2013), perhitungan menggunakan tinggi bahu posisi duduk oleh persentil kecil, agar pengguna dapat tetap bebas bergerak. Menurut Purnomo (2013), tinggi sandaran tangan yang harus berada tepat dengan tinggi siku posisi duduk dari pengguna berukuran tubuh kecil, tujuannya agar pengguna dapat mengistirahatkan tangannya dengan mudah.

Menurut Purnomo (2013) perhitungan untuk lebar alas duduk menggunakan persentil 95 dalam perhitungannya agar pengguna bertubuh besar dapat menggunakan kursi tersebut, dan pengguna bertubuh kecil juga tidak terganggu terhadap ukuran tersebut. Menurut Panero dan Zelnik (2003), kedalaman alas duduk yang ideal harus dapat mengakomodasi jarak lipat lutut ke pantat tetapi tetap memperhatikan pengguna berukuran tubuh kecil, agar kaki pengguna tidak menggantung dan menyebabkan peredaran darah tidak lancar. Purnomo (2013) perhitungan untuk lebar alas duduk dan sandaran punggung menggunakan persentil 95 dalam perhitungannya agar pengguna bertubuh besar dapat menggunakan kursi tersebut, dan pengguna bertubuh kecil juga tidak terganggu terhadap ukuran tersebut. Menurut Purnomo (2013), sudut normal untuk sandaran kursi adalah $100-110^{\circ}$, semakin besar sudut sandaran punggung semakin besar beban tulang punggung ditopang oleh sandaran tersebut. Penentuan sudut sandaran kursi perlu disesuaikan dengan kebutuhan, untuk sandaran kursi di atas sebaiknya menjadi $100^{\circ}$ agar mahasiswa tetap fokus dan rileks dalam melakukan aktivitasnya.

Sementara itu, dilakukan pula analisis ukuran loker sebagai tempat penyimpanan berbagai perlengkapan. Hasil analisis disajikan seperti Tabel 4.

Tabel 4

Analisis Perhitungan Usulan Ukuran Loker

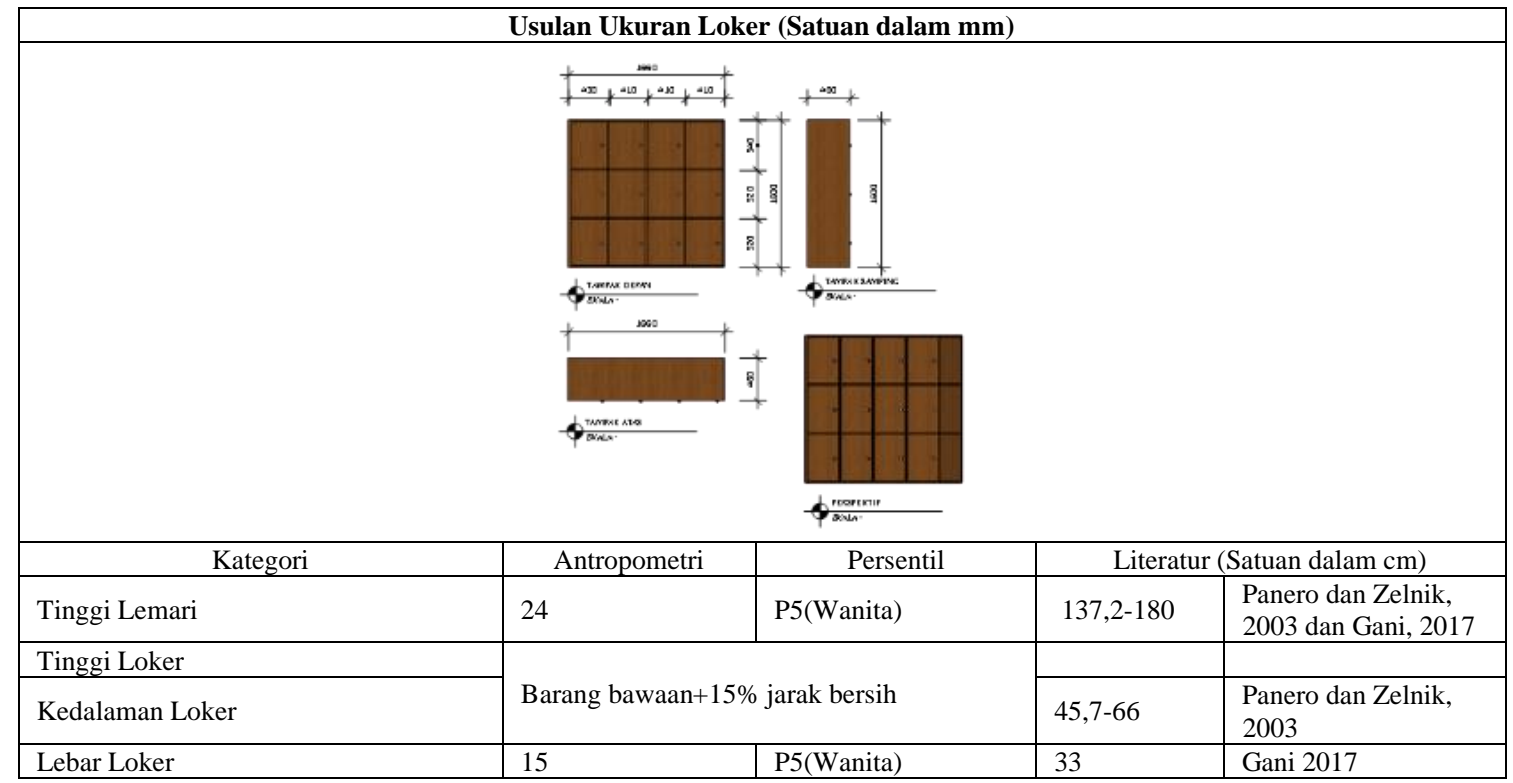

Tinggi Lemari Menurut Gani (2017), jangkauan maksimal untuk mencapai lemari tertinggi menggunakan perhitungan dari tinggi tangan vertikal ke atas posisi berdiri oleh persentil 5, agar seluruh pengguna dapat dengan mudah mencapai tinggi maksimalnya. Menurut kuisioner tanggapan mahasiswa, rata-rata menyatalan barang bawaan adalah A3 tinggi maksimal $43 \mathrm{~cm}$, tas laptop lebar maksimal $39 \mathrm{~cm}$. Sehingga untuk mendapatkan ukuran minimal untuk loker barang bawaan ditambahkan dengan $15 \%$ untuk jarak bersih. Menurut Gani (2017), untuk menentukan lebar loker minimal dapat mempertimbangkan ukuran dari lebar bahu persentil 5 . 
Salah satu hal penting yang perlu diperhitungkan adalah ukuran display yang akan dipasang. Hasilanalisis seperti pada Tabel 5.

Tabel 5

Analisis Perhitungan Usulan Ukuran Display

\begin{tabular}{|c|c|c|c|c|}
\hline \multicolumn{5}{|c|}{ Usulan Ukuran Display (Satuan dalam mm) } \\
\hline & $\phi$ & 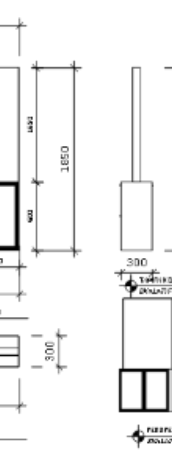 & & \\
\hline Kategori & Antropometri & Persentil & & atuan dalam $\mathrm{cm}$ ) \\
\hline Tinggi Display Maksimum & 2 & $\mathrm{P} 5+30^{\circ}$ & 172,7 & $\begin{array}{l}\text { Panero dan Zelnik, } 2003 \\
\text { dan Purnomo, } 2013\end{array}$ \\
\hline Jarak Pandang Mata & $80 \mathrm{~cm}$ diketahui & data lapangan & $45,7-75$ & $\begin{array}{l}\text { Purnomo, } 2013 \\
\text { danPanero dan Zelnik, } \\
2003\end{array}$ \\
\hline Maksimum Rotasi Mata & & & $30^{\circ}$ & $\begin{array}{l}\text { Tilley, } 2002 \text { danPanero } \\
\text { dan Zelnik, } 2003\end{array}$ \\
\hline
\end{tabular}

Menurut Purnomo (2013), dalam penentuan standar ukuran maksimal pandangan display dapat menggunakan ukutan tinggi mata posisi berdiri oleh persentil kecil agar pengguna bertubuh kecil tetap dapat memandang bagian tertinggi dari display. Menurut Panero dan Julis (2003) sudut maksimal rotasi mata adalah $30^{\circ}$. Sehingga untuk menentukan tinggi makismal display perlu menggunakan rumus trigonometri (sisi, sisi, sudut). Diketahui sudut rotasi mata $30^{\circ}$, jarak maksimum pandangan mata $(80 \mathrm{~cm})$, hasilnya $(46 \mathrm{~cm})$ akan ditambahkan dengan tinggi mata posisi duduk P5 wanita $(139 \mathrm{~cm})$, menjadi $185 \mathrm{~cm}$.

Selanjutnya dilakukan analisis ukuran pintu sebagai jalur lalu lintas keluar masuk. Hasil analisis disajikan seperti pada Tabel 6.

Tabel 6

Analisis Perhitungan Usulan Ukuran Pintu

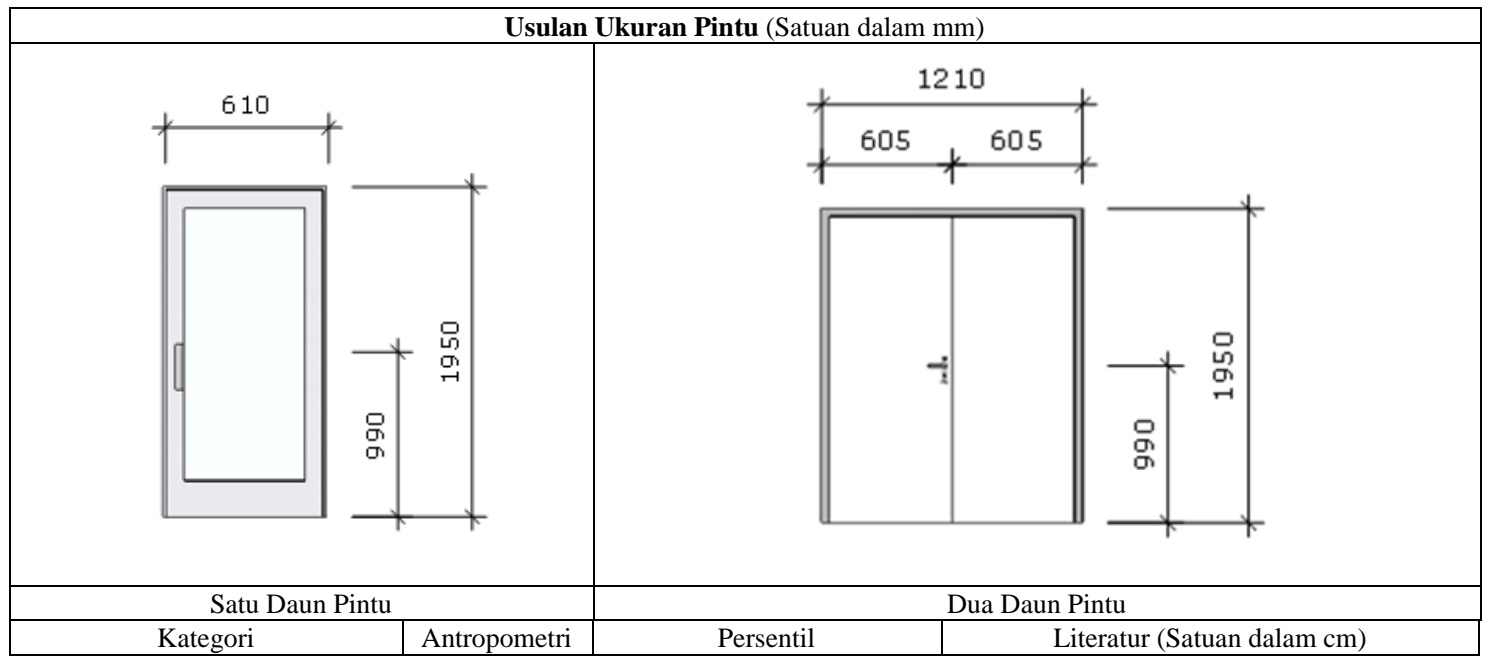




\begin{tabular}{|l|l|l|l|l|}
\hline Ketinggian Pintu & 1 & $\begin{array}{l}\text { P95(Pria)+3 cm sepatu+5 } \\
\mathrm{cm} \text { topi+5 cm bebas }\end{array}$ & 210-240 & $\begin{array}{l}\text { Akmal, 2020 dan } \\
\text { Nurmianto 2004 }\end{array}$ \\
\hline Lebar Pintu & 15 & $\begin{array}{l}\text { (P95(Pria)+15\% jarak } \\
\text { bersih)x2 daun pintu }\end{array}$ & $80-90$ & $\begin{array}{l}\text { Akmal, 2020 dan } \\
\text { Purnomo, 2013 }\end{array}$ \\
\hline Ketinggian Handle & 4 & P50(Wanita) & 114,3 & Akmal,2020 \\
\hline
\end{tabular}

Dalam menghitung ketinggian pintu perlu memikirkan kemungkinan yang terjadi seperti menambahkan perhitungan ukuran topi dan sepatu (Nurmianto, 2004), sehingga ukuran pintu didapatkan dari tinggi berdiri persentil 95 ditambahkan ukuran topi dan sepatu. Menggunakan persentil 95 agar pintu dapat digunakan oleh semua ukuran pengguna. Pada pintu ini, karena memiliki 2 daun pintu perlu memperhitungkan kemunginan 2 orang yang akan menggunakan pintu tersebut, sehingga perhitungan dari lebar bahu persentil 95 dikali 2 orang dan ditambah jarak bersih $15 \%$ untuk kemungkinan seseorang menggunakan tas. Ketinggian handle perlu menggunakan perhitungan tinggi siku berdiri, dan agar ukuran dapat universal keseagal ukuran tubuh, maka menggunakan tinggi rata-rata (P50) untuk dapat memperhatikan kesanggupan jangkauan.

\section{SIMPULAN}

Hasil analisis menyatakan bahwa perbandingan antropometri mahasiswa Program Studi Desain Interior Universitas ' $\mathrm{X}$ ' berdasarkan jenis kelamin sangat berbeda. Perbedaan ukuran tersebut dapat mempengaruhi perhitungan untuk ukuran mebel agar dapat sesuai dengan ukuran tubuh dari kedua jenis kelamin. Berdasarkan antropometri mahasiswa Universitas ' $\mathrm{X}$ ', ukuran masing-masing mebel yang telah dihitung berdasarkan antropometri pengguna dengan membandingkan data literatur.

Dengan hasil olahan data antropometri mahasiswa tersebut, peneliti menghasilkan ukuran mebel yang telah disesuaikan melalui pengamatan dan perhitungan berdasarkan sumber literatur terhadap ukuran penggunanya.

Peneliti memberikan usulan ukuran mebel baru dengan tujuan dapat sesuai dengan ukuran tubuh dan kebutuhan dari penggunanya. Hasil penelitian ini kiranya dapat membantu pengguna beraktivitas dengan mebel yang sesuai dengan ukuran kebutuhan pengguna sebenarnya, tentunya usulan ukuran ini dapat dipertimbangkan lagi melalui pengamatan aktivitas pengguna yang berbeda.

\section{DAFTAR PUSTAKA}

Iridiastadi, H. dan Yassierli.2015.Ergonomi Suatu Pengantar (2nd ed.). Bandung: PT. Remaja Rosdakarya.

Ismaila, S.O., Musa, A.I., Adejuyigbe, S.B., dan Akinyemi, O.D. 2013. Anthropometric Design of Furniture for Use in Tertiary Institutions in Abeokuta, Southwestern Nigeria. Engineering Review. Vol. 33(3):184-189.

Kroemer, K.H.E dan E. Grandjean.1997. Fitting The Task To Human (5th ed.). New York: Taylor \& Francis Group.

Lawson, S. 2013. Furniture Design. London: Laurence King Publishing.

Mckeown, C. 2008. Office Ergonomics Practical Applications. London: Taylor \& Francis Group.

Nurmianto, E. 2004. Ergonomi Konsep Dasar Dan Aplikasinya (2nd ed.). Surabaya: Prima Printing. 2004.

Octivjani, C. 2011. "Kajian Antropometri Terhadap Studio Tugas Akhir Jurusan Desain Interior Universitas Kristen Petra Surabaya" (thesis). Universitas Kristen Petra. 
Panero, J. dan Martin Z. 2003. Dimensi Manusia Dan Ruang Interior. Trans. Djoeliana Kurniawan. Jakarta: Erlangga.

Purnomo, H. 2013. Antropometri dan Aplikasinya. Yogyakarta: Graha Ilmu.

Tarwaka, Solichul H.A.B dan Sudiajeng, L. 2004. Ergonomi untuk keselamatan, kesehatan kerja dan produktivitas. Surakarta: Universitas Islam Batik.

Tilley, A.R. 2002. The Measure Of Man And Woman Revised Edition. New York: Whitney Library of Design. 